\title{
IN THE KINGDOM OF SHOES
}

Bata, Zlín, Globalization, 1894-1945

One of the world's largest sellers of footwear, the Bata Company of Zlín, Moravia, has a remarkable history that touches on crucial aspects of what made the world modern. In the twilight of the Habsburg Empire, the company Americanized its production model while also trying to Americanize its workforce. It promised a technocratic form of governance in the chaos of postwar Czechoslovakia, and during the Roaring Twenties, it became synonymous with rationalization across Europe and thus a flashpoint for a continent-wide debate. While other companies contracted in response to the Great Depression, Bata did the opposite, becoming the first shoe company to unlock the potential of globalization.

As Bata expanded worldwide, it became an example of corporate national indifference, where company personnel were trained to be able to slip into and out of national identifications with ease. Such indifference, however, was seriously challenged by the geopolitical crisis of the 1930s, and by the cusp of the Second World War, Bata management had turned nationalist, even fascist.

In the Kingdom of Shoes unravels the way the Bata project swept away tradition and enmeshed the lives of thousands of people around the world in the industrial production of shoes. Using a rich array of archival materials from two continents, the book answers how Bata's rise to the world's largest producer of shoes challenged the nation-state, democracy, and Americanization.

ZACHARY AUSTIN DOLESHAL is a clinical assistant professor in the Department of History at Sam Houston State University. 
This page intentionally left blank 


\section{ZACHARY AUSTIN DOLESHAL}

\section{In the Kingdom of Shoes}

Bata, Zlín, Globalization, 1894-1945 
(C) University of Toronto Press 2021

Toronto Buffalo London

utorontopress.com

Printed in the U.S.A.

ISBN 978-1-4875-0658-2 (cloth)

ISBN 978-1-4875-3447-9 (EPUB)

ISBN 978-1-4875-2444-9 (paper)

ISBN 978-1-4875-3446-2 (PDF)

\section{Library and Archives Canada Cataloguing in Publication}

Title: In the kingdom of shoes : Bata, Zlín, globalization, 1894-1945 / Zachary Austin Doleshal.

Names: Doleshal, Zachary Austin, author.

Description: Includes bibliographical references and index.

Identifiers: Canadiana (print) 20210260807 | Canadiana (ebook) 20210264470 | ISBN 9781487506582 (hardcover) | ISBN 9781487524449 (softcover) | ISBN 9781487534479 (EPUB) | ISBN 9781487534462 (PDF)

Subjects: LCSH: Bata Shoe Company - History. | LCSH: Footwear industry - Czech Republic - Zlín - History - 20th century. | LCSH: Company towns - Czech Republic Zlín - History - 20th century. | LCSH: Labor and globalization - Czech Republic History - 20th century. | LCSH: World War, 1939-1945 - Czechoslovakia. | LCSH: Corporate culture - Czech Republic - Zlín - History - 20th century. | LCSH: Zlín (Czech Republic) - History - 20th century. | LCSH: Zlín (Czech Republic) - Social conditions -20 th century.

Classification: LCC HD9787.C944 B383 2021 | DDC 338.4/768530943725 - dc23

Chapter opening ornament from https://all-free-download.com/free-vector/different-shoes .html.

Publication of this book was made possible, in part, by a grant from the First Book Subvention Program of the Association for Slavic, East European, and Eurasian Studies.

University of Toronto Press acknowledges the financial assistance to its publishing program of the Canada Council for the Arts and the Ontario Arts Council, an agency of the Government of Ontario.

Canada Council for the Arts
Conseil des Arts du Canada

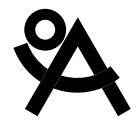

ONTARIO ARTS COUNCIL CONSEIL DES ARTS DE L'ONTARIO

an Ontario government agency un organisme du gouvernement de l'Ontario 
For Leslie Lee 
This page intentionally left blank 